Elsevier required licence: (C) <2018>. This manuscript version is made available under the CC-BY-NC-ND 4.0 license http://creativecommons.org/licenses/by-nc-nd/4.0/ 


\section{A critical review on ammonium recovery from wastewater for sustainable wastewater}

\section{management}

Yuanyao Ye $e^{a}$, Huu Hao Ngo ${ }^{a,}$, Wenshan Guo ${ }^{a}$, Yiwen Liu ${ }^{a}$, Soon Woong Chang ${ }^{b}$, Dinh Duc Nguyen ${ }^{b}$, Heng Liang ${ }^{\mathrm{c}}$, Jie Wang ${ }^{\mathrm{d}}$

${ }^{a}$ Centre for Technology in Water and Wastewater, School of Civil and Environmental Engineering, University of Technology Sydney, Sydney, NWS 2007, Australia

${ }^{b}$ Department of Environmental Energy and Engineering, Kyonggi University, 442-760, Republic of Korea

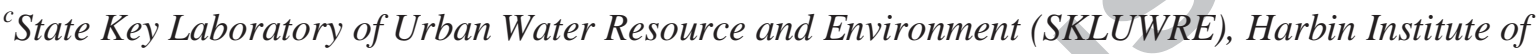
Technology, 73 Huanghe Road, Nangang District, Harbin, 150090, P.R. China

${ }^{d}$ School of Environmental and Chemical Engineering, Tianjin Poytechnic University, Tianjin 300387, China

*: Corresponding authors: H. H. Ngo; E-mail address: ngohuuhao121@gmail.com 


\section{Abstract}

The growing global population's demand for ammonium has triggered an increase in its supply, given that ammonium plays a crucial role in fertilizer production for the purpose of food security. Currently, ammonia used in fertilizer production is put through what is known as the industrial Haber Bosch process, but this approach is substantially expensive and requires much energy. For this reason, looking for effective methods to recover ammonium is important for environmental sustainability. One of the greatest opportunities for ammonium recovery occurs in wastewater treatment plants due to wastewater containing a large quantity of ammonium ions. The comprehensively and critically review studies on ammonium recovery conducted, have the potential to be applied in current wastewater treatment operations. Technologies and their ammonium recovery mechanisms are included in this review. Furthermore the economic feasibility of such processes is analysed. Possible future directions for ammonium recovery from wastewater are suggested.

Keywords: ammonium recovery, wastewater, struvite precipitation, ammonium salts, membrane hybrid system 


\section{Introduction}

The combination of wastewater, concerns for people's health and environmental hazard, is one where basic engineering seeks to remove contaminants from wastewater treatment plants, so that a satisfactory effluent is generated (Taddeo et al., 2018). However, substantial energy and resources such as land and infrastructure are important aspects of wastewater treatment. A high quantity of sludge is generated during this process, one which may pose a risk to the environment. Fortunately, remediation methods have changed and more attention is being paid to make wastewater treatment facilities more sustainable (Mulchandani \& Westerhoff, 2016; Smith \& Smith, 2015; Tarayre et al., 2016). This may be attributed to the increasing market value of the components available in wastewater, including fresh water, metals, nutrients such as ammonium and energy, which are expected to be recovered (Luo et al., 2018; Yan et al., 2018). More importantly, people are much more aware of the need to consume less non-renewable energy and natural resources. Consequently, the emphasis is on wastewater being regarded as a renewable resource and one that is increasingly valued (Lin et al., 2016).

Nitrogen $(\mathrm{N})$ as the renewable resource is of great importance for organisms' growth (Smith \& Smith, 2015). The natural nitrogen cycle is present in Figure 1 and it can be seen that the main nitrogenous compounds involved in the natural $\mathrm{N}$ cycle include nitrogen gas $\left(\mathrm{N}_{2}\right)$, ammonium ion $\left(\mathrm{NH}_{4}{ }^{+}\right)$, organic nitrogen, nitrate $\left(\mathrm{NO}_{3}{ }^{-}\right)$and nitrite $\left(\mathrm{NO}_{2}{ }^{-}\right)$. There is abundant $\mathrm{N}_{2}$ in the atmosphere but it cannot be directly taken up by organisms due to the molecular nitrogen lacking reactivity. For this reason, biological nitrogen fixation is commonly utilized for crops and plants to adsorb $\mathrm{N}_{2}$ in its reactive forms through nitrogenase (conversion to ammonium) and lightning (conversion to nitric oxide), respectively. Then, the ammonium is converted to nitrite by ammonium oxidizing microorganisms, followed by transformation into nitrate via nitrite oxidizing microorganisms (Li et al., 2018). This process 
is called nitrification. In contrast, denitrification is referred to as the reduction of nitrate to molecular nitrogen by denitrifying microorganisms. Ammonia with nitrite as an electron acceptor can be oxidized to nitrogen gas through anaerobic ammonium oxidation bacteria (Ye et al., 2018). It is worth noting that the ammonium derived from the biological nitrogen fixation is not enough to support the world's ammonia demand for crops and plants. Therefore, an approach known as the Haber-Bosch process is applied at the industrial scale to produce ammonia with molecular nitrogen used as the raw material, which is further employed in fertilizer production. The equation of this particular process is presented in Eq. (1):

$$
\mathrm{N}_{2}+3 \mathrm{H}_{2} \rightarrow 2 \mathrm{NH}_{3}
$$

With the world's population increasing, it was reported that more fertilizer production is needed; in fact, it has been suggested it should increase at an annual rate of around $1.8 \%$ to ensure food security (Ledezma et al., 2015). Thus, the industrial Haber-Bosch process may be excessively used to satisfy rising demand for fertilizer. However, the fact that the amount of ammonia achieved in industry exceeds that obtained via biological nitrogen fixation may have serious consequences for the natural nitrogen cycle, in fact damaging the environment and even human health (Erisman et al., 2013; Fowler et al., 2013). More importantly, Heffer and Prud'homme (2014) stated that the amount of global fertilizer production is estimated to reach 199.4 million tonnes by 2018 , which means the ammonia supply averagely increases at $1.5 \%$ per year. As a reference, current world fertilizer consumption (2020 projection) is 118 MT (FAO, 2017). Moreover, the industrial Haber-Bosch process for ammonia production is energy-intensive, in which $1-2 \%$ of annual global energy supply is consumed in this way (Nancharaiah et al., 2016). Unfortunately, greenhouse gases are generated through this production method (Galloway \& Cowling, 2002), and this has serious health implications for people, societies and the natural environment. Therefore, looking for renewable methods 
other than the Haber-Bosch process to sustainably produce ammonia for fertilizer production is a problem that must be urgently solved.

Ammonia-based fertilizers eventually enter the aquatic environment by runoff while nitrogenous compounds consumed by human and animals through crops will also reach water bodies in the major forms of sewage and manure, respectively. This may increase the concentration of ammonium (nitrogenous compounds exist in the main form of ammonium ions in water) in the aquatic environment. Once the ammonium concentration cannot be purified by the water itself, several environmental issues such as eutrophication will arise (Ye et al., 2016a; Ye et al., 2017). Eutrophication causes the death of aquatic life such as fish, degrades water quality and destroys biodiversity (Ye et al., 2016b). Furthermore, high concentrations of nitrogen oxides may contribute to blue baby syndrome and cancers (Fowler et al., 2013; Nancharaiah \& Venugopalan, 2011). For these reasons, nitrogen/ammonium removal from wastewaters is must be undertaken to ensure human health and sustainable development.

In the current wastewater treatment system, ammonium is conventionally removed through nitrification and denitrification and ends up being converted into harmless gaseous $\mathrm{N}_{2}$. However, this method requires large amounts of energy, where the aeration for nitrification alone occupies around 50\% of total energy (Foley et al., 2010) and 60\% of the operation cost involved in the wastewater treatment (Ledezma et al., 2015). Moreover, a substantial chemical input is necessary since various chemicals must serve as the electron donor in the nitrification-denitrification process. By-products such as nitrate resulting from the nitrification-denitrification process do not have significant market values and often need further purification prior to their emission.

As discussed above, a sustainable supply of ammonia and efficient ammonium removal mechanism is important. Hence, ammonium recovery in wastewater treatment seems more 
valuable than ammonia removal, especially given that high energy and costs beset the classical ammonium removal processes. Apart from this, ammonium recovery can not only supplement fertilizer production, but also lead to sustainable and better resource management. A combination of wastewater sources such as municipal wastewater, piggery wastewater, landfill leachate and urine are ammonium-dense, as shown in Table 1.

A focus on reducing the environmental footprint that is part of classical ammonium removal, yet at the same time it must increase the amount of ammonium for fertilizer production. This has triggered much research on recovering ammonium from wastewater. Some reviews have summarized ammonium recovery in the context of wastewater treatment (Barbera et al., 2018; Huang et al., 2017b; Iskander et al., 2016). Firstly, however, most reviews lack detailed technical and economic analyses of ammonium recovery processes; and secondly they did not comprehensively assess the main methods of ammonium recovery in the current wastewater treatment. Here, we critically review ammonium recovery in wastewater treatment, particularly with respect to comparing such technologies including technical and economic performance. The possible challenges involved in the development of ammonium recovery in wastewater treatment are elaborated as well as future possible improvements. We assert that this review can provide some recommendations for future work on diversified technologies that can recover ammonium efficiently and effectively.

\section{Mechanism of ammonium recovery in the wastewater treatment}

It is important to comprehend the mechanisms of ammonium recovery in wastewater treatment because they provide useful information on optimizing the recovery process and subsequent application of recovered ammonium in large-scale scenarios. There are three main ammonium recovery mechanisms, namely: (i) struvite precipitation; (ii) ammonia stripping coupled with adsorption and (iii) membrane concentration (Huang et al., 2014; Sotres et al., 2015; Xie et al., 2016; Yan et al., 2018). 


\subsection{Struvite precipitation}

The first mechanism is most commonly used to recover ammonium from wastewater. In this process, the ammonium is recovered in the form of struvite with simultaneous phosphate recovery at alkaline $\mathrm{pH}$. It should be noted here that the struvite formation needs stoichiometric amounts of ammonium, phosphate and magnesium as described in Equation (2) (Abbona et al., 1982).

$$
\mathrm{Mg}^{2+}+\mathrm{PO}_{4}{ }^{3-}+\mathrm{NH}_{4}^{+}+6 \mathrm{H}_{2} \mathrm{O} \rightarrow \mathrm{MgNH}_{4} \mathrm{PO}_{4} \cdot 6 \mathrm{H}_{2} \mathrm{O} \downarrow
$$

It is well known that phosphate and ammonium ions may undergo hydrolyzation at different $\mathrm{pH}$ values, which can in turn affect to some extent struvite precipitation. Changes in $\mathrm{pH}$ could result in different species of phosphate and ammonium ions, which is accounted for in the following equations (Dai et al., 2014; Qin et al., 2003).

$$
\begin{aligned}
& \mathrm{NH}_{4}{ }^{+} \rightleftharpoons \mathrm{H}^{+}+\mathrm{NH}_{3}(\mathrm{aq})\left(p K_{a}=9.3\right) \\
& \mathrm{H}_{2} \mathrm{PO}_{4}{ }^{-} \rightleftharpoons \mathrm{H}^{+}+\mathrm{HPO}_{4}{ }^{2-}\left(p K_{a}=7.2\right) \\
& \mathrm{HPO}_{4}{ }^{2-} \rightleftharpoons \mathrm{H}^{+}+\mathrm{PO}_{4}{ }^{3-}\left(p K_{a}=12.33\right)
\end{aligned}
$$

According to Equation (3), a downward trend in the $\mathrm{pH}$ value would be observed while applying struvite precipitation to recover ammonium. This may in turn shift the equilibrium towards increasing the ammonium concentration. As result of this, it is more likely for $\mathrm{HPO}_{4}{ }^{2-}$ ions to be involved in struvite formation rather than $\mathrm{PO}_{4}{ }^{3-}$ (see Eq. [5]) (Schuiling \& Andrade, 1999). In this scenario, struvite precipitation can be described by Eq.(6) (Schuiling \& Andrade, 1999).

$$
\mathrm{Mg}^{2+}+\mathrm{HPO}_{4}{ }^{2-}+\mathrm{NH}_{4}^{+}+6 \mathrm{H}_{2} \mathrm{O} \rightarrow \mathrm{MgNH}_{4} \mathrm{PO}_{4} \cdot 6 \mathrm{H}_{2} \mathrm{O} \downarrow+\mathrm{H}^{+}
$$

Tansel et al. (2018) stated that struvite precipitation may also occur in conditions affected by pressure, such as water hammer and filtration systems with high ionic concentration, as shown in Eq. (6). 


\subsection{Ammonium stripping}

As well, ammonium recovery through the stripping-adsorption process is mainly attributed to the fact that at high reaction temperature and/or $\mathrm{pH}$, the ammonium can be converted to volatile ammonia. This reaction can be described in Eq. (7).

$\mathrm{NH}_{3}+\mathrm{H}_{2} \mathrm{O} \rightleftharpoons \mathrm{NH}_{4}^{+}+\mathrm{OH}^{-}$

Thus, one method to recover ammonium from wastewater is to shift the equilibrium toward the gaseous phase, followed by ammonia stripping from the solution. In this scenario, the stripped ammonia can be adsorbed by acid solutions to form ammonium salts such as ammonium sulphate $\left[\left(\mathrm{NH}_{4}\right)_{2} \mathrm{SO}_{4}\right]$ via a diluted sulphuric acid solution. Alternatively, it can be harvested in the liquid ammonia as an ammonia-rich solution. Specifically, the $\mathrm{pH}$ elevation coupled with agitation and turbulence of solution can result in the conversion of ammonium in the solution to volatile ammonia in the air stream. Alternatively, the ammonium-rich solution can also generate the volatile ammonia through being heated. It is worth noting that El-Bourawi et al. (2007) believed that the $\mathrm{pH}$ value plays a more important role in the generation of volatile ammonia than the reaction temperature.

\subsection{Membrane concentration}

Membrane technology can enrich ammonium and separate it from foreign substances (e.g. heavy metals and pathogen) with low energy input, so membrane concentration for ammonium recovery is also an economic approach. The technically feasible membrane technology to recover ammonium mainly includes forward osmosis (FO), reverse osmosis (RO), membrane distillation (MD) and electrodialysis (ED).

In FO, natural osmotic pressure is used to force movement of water molecules from the feed side to draw side (Gao et al., 2018). Consequently, ammonium can be concentrated in the feed side. In contrast to this, RO relies on the hydraulic pressure which is against the osmotic pressure between the feed solution and draw solution (Mondor et al., 2008). In this 
scenario, water molecules can be driven from low concentration of solute to high concentration of solute. Actually, the mechanism of ammonium concentration through the RO system is similar to that via the FO membrane. This is despite the fact that more energy is consumed in the RO process compared to the FO process. The main drawback associated with the FO process for ammonium recovery is that the draw solute is gradually diluted, which decreases the osmotic pressure gradient and thus detrimentally affects the ammonium concentration in the feed side. Moreover, the electrical property of FO membrane surface is shifted to be negatively charged at alkaline $\mathrm{pH}(>7)$ (Cartinella et al., 2006). According to Eq. (3), the surface of FO membrane can adsorb the ammonium ions in the feed solution under alkaline environment due to electrostatic attraction. Then the ammonium ions can permeate into the draw side. Furthermore, the $\mathrm{NH}_{3}(\mathrm{aq})$ is predominant form of ammonium at $\mathrm{pH}>9.3$ and the Donnan exclusion indicates that $\mathrm{NH}_{3}(\mathrm{aq})$ is more easily transferred across the charged membrane than $\mathrm{NH}_{4}{ }^{+}$ions (Xue et al., 2015). As a result of this, the concentration of ammonium enriched in the feed side may decrease. Apart from that, high $\mathrm{pH}$ may result in the generation of volatile ammonia. Therefore, the $\mathrm{pH}$ control of feed solution is important while using the FO process to recover ammonium.

In the MD system, the feed solution is heated, which results in the temperature gradient between the feed side and permeate side (Rao et al., 2018). In this case, the ammonium ions are converted to volatile form and then driven to transfer across the MD membrane (i.e. microporous hydrophobic membrane). It is worth noting that the MD membrane can avoid the permeation of liquid substances. Consequently, the ammonium ions can be condensed in the permeate side at lower temperature. Some acid solutions such as hydrochloric acid are always utilized as the receiving solution in the permeate side since they can react with volatile ammonia to form ammonium salts which have high potential in the practical 
application (Ahn et al., 2011). The MD process to concentrate ammonium is similar to the ammonium stripping, which is largely affected by $\mathrm{pH}$ and temperature of the feed solution.

A cation-exchange membrane (CEM) is used in the ED process. The ammonium ions are driven by an electrical current to diffuse the CEM towards the cathode chamber, which causes the ammonium retention in an individual compartment. High current density certainly improves the ammonium concentration, but also contributes to large energy consumption in the ED system.

\section{Membrane technology for ammonium recovery from wastewater}

Generally, wastewater contains a mix of substances such as organics, heavy metals and toxic substances, which may seriously affect the ammonium recovery process. The biological process is the most widely used mechanism for treating wastewater because it can reduce the amount of foreign matter. As a result, ammonium ions with high purity can be achieved within the reactor and this facilitates the ammonium recovery. Nevertheless, more effort should be made to separate the ammonium from foreign substances to enhance ammonium recovery. For this reason, efficient membrane technology is proposed because it can enrich the ammonium ions within the reactor and separate the foreign matter from ammonium without energy input. Using membrane technology to concentrate ammonium ions is a lowcost exercise. In addition, integration of membrane technology with biological process can enhance the organic removal and thereby reduce the membrane fouling which seriously influences the membrane application. For example, the MD membrane is easily subjected to high organic fouling while applying it to recover ammonium in the wastewater treatment. In this scenario, membrane wetting will be caused, which results in the diminished amount of ammonium diffused and negatively affects the subsequent ammonium recovery (Zarebska et al., 2015). Similarly, the membrane fouling may also reduce the electrical conductivity in the ED process, resulting in higher energy input and serious effects on further ammonium 
recovery (Mondor et al., 2009). In fact, membrane technology integrated with struvite precipitation and/or stripping-adsorption has attracted a great deal of attention for recovering ammonium from biological wastewater treatment.

\subsection{Bioelectrochemical system}

The bioelectrochemical system (BES) has been developed for recovering ammonium in wastewater treatment (Iskander et al., 2016; Kelly \& He, 2014; Liu et al., 2017; Nancharaiah et al., 2016). The advantage of BES is that it can purify wastewater and recover energy stored in organics at the same time (Yang et al., 2017). Microbial fuel cells (MFCs) and microbial electrolysis cells (MECs) which are the essence of BES, are mostly used for ammonium recovery from wastewater. Typically, BES consists of an anode chamber and a cathode chamber, in which a CEM is installed to separate the two chambers. In the anode chamber, the organic substances are oxidized to carbon dioxide $\left(\mathrm{CO}_{2}\right)$ through anaerobic microorganisms, in which the anode electrode functions as the terminal electron acceptor (Logan et al., 2006). The basic principles of MFC and MEC are present in Figure 2. Specifically, the electrons are released from the organic substrate by the metabolic reaction of anaerobic microorganisms and then transferred to the anode electrode due to having greater potential than organics. The mechanisms of extracellular electron transport depend on combined effects of direct, electron shuttle and biofilm matrix or pili mediation, through which electrons can be shunted to the anode electrode (i.e. electron acceptor) that is located outside the cells. In this scenario, the energy used for anaerobic microorganisms' growth can be saved. Subsequently, the released electrons transfer from the anode electrode to the cathode electrode via an external circuit containing a resistor. Then these electrons are ultimately reduced by the electron acceptors such as oxygen gas in the cathode chamber (Logan et al., 2008; Logan et al., 2006). Glucose degradation is taken as an example to explain the anode reaction in the MFC and MEC as shown below. 


$$
\mathrm{C}_{6} \mathrm{H}_{12} \mathrm{O}_{6}+12 \mathrm{H}_{2} \mathrm{O} \rightarrow 6 \mathrm{HCO}_{3}^{-}+30 \mathrm{H}^{+}+24 \mathrm{e}^{-}
$$

As for the cathode reaction, it differs in the MFC and MEC, where the electricity is generated by the reduction of electron acceptor (e.g. $\mathrm{O}_{2}$ ) in the MFC (Logan et al., 2006) while the reduction of protons drives the electron flow and generates the hydrogen gas (Logan et al., 2008). The different cathode reactions in the MFC and MEC are shown in Eqs. (9)-(10).

Cathode reaction in MFC: $2 \mathrm{H}_{2} \mathrm{O}+\mathrm{O}_{2}+4 \mathrm{e}^{-} \rightarrow 4 \mathrm{OH}^{-}$

Cathode reaction in MEC: $2 \mathrm{H}_{2} \mathrm{O}+2 \mathrm{e}^{-} \rightarrow \mathrm{H}_{2} \uparrow+2 \mathrm{OH}^{-}$

Except for electrons, the protons are also produced during the anaerobic microbial degradation in the anode chamber and travel from the anode chamber to the cathode chamber via the CEM. In this scenario, the protons are consumed by the hydroxyl ions $\left(\mathrm{OH}^{-}\right)$in the cathode chamber (see Eqs. [9]-[10]). The subsequent consumption of protons can avoid their accumulation in the anode chamber, which may acidify the anaerobic sludge and decrease the metabolic and the anaerobic microorganisms' electroactivity (Patil et al., 2011).

The BES can result in the conversion of ammonium into volatile ammonia. Firstly, ammonium transport from the anode chamber to the cathode chamber across the CEM is driven by diffusion caused by the concentration gradient and migration associated with the electrical field. Furthermore, ammonium diffusion is related to the concentration gradient and becomes weak with decreasing concentration gradient; in contrast, ammonium migration is only affected by the current density. Thus, the accumulated ammonium in the catholyte has a good chance of being transformed into $\mathrm{NH}_{3}(\mathrm{aq})$ because of high $\mathrm{pH}$ as a result of the hydroxyl ions generation (Eqs. [9] and [10]). It was reported that the $\mathrm{pH}$ localized in the cathode electrode could reach up to 12 (Rozendal et al., 2009). The $\mathrm{NH}_{3}$ (aq) could be stripped by either air or $\mathrm{N}_{2}$ and thus converted to volatile ammonia. Therefore volatile 
ammonia can be created in liquid form or adsorbed by the acid solutions to form ammonium salts.

Kim et al. (2015) coupled MFC with the anaerobic digester to recover ammonia from actual swine wastewater, where the anaerobic digester was employed to convert organic nitrogen into ammonia for the ammonium enrichment; the anaerobic digester is not able to remove nitrogenous compounds. The authors found that: firstly, increased organic loading rates can enhance the ammonium migration from the anode chamber to the cathode chamber; and secondly, coexisting cations in the influent had serious impacts on ammonium transfer across the CEM from the anolyte to the catholyte and further worsened the ammonium recovery. Similarly, Wu and Modin (2013) developed a MEC for the simultaneous recovery of ammonium and energy, in which the anode chamber received the synthetic wastewater while synthetic or real reject water served as the catholyte. The efficiencies in recovering ammonium were $94 \%$ for synthetic reject waster as the catholyte and $97 \%$ for real reject water as the catholyte, while passing the volatile ammonia through the hydrochloric solution whose concentration was $2 \mathrm{~mol} / \mathrm{L}$. It should be mentioned that the sodium chloride $(\mathrm{NaCl})$ solution used as the catholyte of MEC can promote the stripping/absorption process in the cathode chamber due to facilitating the $\mathrm{pH}$ elevation (Sotres et al., 2015).

Overall, MFC and MEC have different strengths and weaknesses. Regarding the ammonium recovery via MEC, the external voltage applied in it can facilitate the ammonium transfer across the CEM and better ammonium concentration in the cathode chamber could be observed compared to the MFC. However, it may be difficult to expel ammonium out of the catholyte without aeration supply in the MEC. For instance, Qin et al. (2016) discovered that a MEC could achieve ammonium enrichment of $8202 \mathrm{mg} / \mathrm{L}$ in the catholyte, but most of the ammonium accumulated remained in the cathode chamber in the absence of aeration. Once the aeration was supplied, $0.77 \mathrm{M}$ of ammonia was recovered after being removed from 
the cathode chamber. MFC can be deemed a positive energy balance system for recovering ammonium from wastewater because the electrons generated by itself drive the ammonium transport for ammonium enrichment and $\mathrm{pH}$ elevation for ammonium transformation. Nevertheless, the current density should be increased if the ammonium recovery via MFC is expected to be improved.

Another feature is that stripped ammonia can be utilized as the draw solute in the forward osmosis (FO) process. This indicates that the integration of BES and FO processes can improve the feasibility of recovering ammonium from wastewater (Qin \& He, 2014; Qin et al., 2016) (see Figure 3). Qin and He (2014) recovered ammonium through a MEC in the form of ammonium bicarbonate $\left(\left[\mathrm{NH}_{4}\right]_{2} \mathrm{CO}_{3}\right)$ which was subsequently utilized as the draw solute for the FO process to recover fresh water. Recovery of ammonium and fresh water from landfill leachate could be successful when utilizing this MEC-FO system (Qin et al., 2016).

The ammonium recovery obtained in the BES can also result in the struvite formation. For example, Ichihashi and Hirooka (2012) employed an air-cathode MFC to recover ammonium in the form of struvite which was formed on the cathode electrode's surface in the swine wastewater treatment. Struvite formation may be ascribed to an increase in $\mathrm{pH}$ near the cathode electrode. Similarly, the single-chamber MEC mode was also found the formation of struvite on the cathode surface at $0.3-0.9 \mathrm{~g} / \mathrm{m}^{2} \cdot \mathrm{h}$ (Cusick \& Logan, 2012). Certainly, the cathode electrode's performance was compromised by the attached struvite, but this issue could be solved after removing such precipitate from the cell (Hirooka \& Ichihashi, 2013).

The simultaneous use of both CEM (for ammonia transfer) and AEM (anion exchange membrane) (for phosphate transport) in the same BES could strongly concentrate ammonium within the reactor (Chen et al., 2015; Zhang et al., 2014), which facilitates its further recovery. For example, Chen et al. (2015) proposed a new MFC by simultaneously using CEMs and 
AEMs to recover ammonium and purify wastewater. In their study, wastewater was circulated between the anode and cathode chambers, which resulted in the concentrations of ammonium condensing to 1.5 times bigger than the initial concentrations. Thus, ammonium was recovered as struvite and $96 \%$ of $\mathrm{NH}_{4}{ }^{+}-\mathrm{N}$ was removed from the wastewater. When a phosphate buffer served as the catholyte, the ammonium recovery could actually improve.

The possible explanation for this is that the phosphate buffer solution could: (i) be used as the phosphate sources for the struvite precipitation; and (ii) increase the ammonium transport from the anode chamber to the cathode chamber as a result of maintaining the ion balance (Sotres et al., 2015).

\subsubsection{Effects of parameters on ammonium recovery via the BES}

\subsubsection{Current density}

High current density can significantly affect the ammonium recovery process in the BES. This is because high current density can increase the ammonium migration across the CEM from the anolyte to the catholyte and facilitate the $\mathrm{pH}$ increase of the latter due to providing more electrons (Kim et al., 2015; Zhang et al., 2014). For example, the acid dissociation constant of ammonium is 9.3 as discussed above (see Eq. [3]), so most of the ammonium ions will be converted to gaseous ammonia at a $\mathrm{pH}$ over 9.3. Wu and Modin (2013) observed that an increase in the current to 10 or $15 \mathrm{~mA}$ could result in the catholyte having a $\mathrm{pH}$ over 12 , which improved the ammonium transport from the anode chamber to cathode chamber. When the current was reduced to $5 \mathrm{~mA}$, however, the catholyte's $\mathrm{pH}$ fell to 8.6, which may negatively influence the formation of volatile ammonia and the later ammonia adsorption.

\subsubsection{Coexisting cations}

Cations other than ammonium ions are also driven by the current field to migrate across the CEM from the anolyte to the catholyte so that the charge neutrality of the BES can be maintained. So the coexisting cations such as $\mathrm{K}^{+}, \mathrm{Na}^{+}$and $\mathrm{Ca}^{2+}$ in the wastewater may affect 
the ammonium migration and further recovery. For the most common cations, Kim et al. (2015) found that the mobility of such cations was in this order: $\mathrm{K}^{+}>\mathrm{NH}_{4}{ }^{+}>\mathrm{Ca}^{2+}>\mathrm{Na}^{+}$. It should be noted that the movement rate of protons is approximately double that of $\mathrm{NH}_{4}{ }^{+}$. It meant that the protons are first driven from the anode chamber to the cathode chamber and the $\mathrm{H}_{2} \mathrm{O}$ is thereby formed, which leads to $\mathrm{pH}$ elevation in the catholyte. The transfer of cations including $\mathrm{K}^{+}, \mathrm{NH}_{4}{ }^{+}, \mathrm{Ca}^{2+}$ and $\mathrm{Na}^{+}$happens after the proton transport. Hence, the ammonium migration may be negatively affected at a relatively low current density of the BES since substantial charges may be initially neutralized by protons and/or $\mathrm{K}^{+}$. More importantly, the ammonium migration plays more critical roles in ammonium transport than ammonium diffusion. Therefore, an increased current density in the BES is necessary to enhance the ammonium migration. Moreover, the catholyte's salinity may be increased as a result of transporting mineral salts from the anode chamber to the cathode chamber.

Consequently, the ability of MFC to generate electricity may be enhanced due to weakening catholyte resistance (Qin et al., 2016), which in turn facilitates the ammonium migration.

The coexisting cations may also affect the ammonium recovery via struvite precipitation in the BES. During struvite formation, the ammonium ions may be substituted by other cations such as $\mathrm{K}^{+}$and $\mathrm{Rb}^{+}$; similarly, $\mathrm{Ca}^{2+}$ and $\mathrm{Zn}^{2+}$ ions can replace magnesium ions during struvite formation (Ravikumar et al., 2010), which undermines the ammonium recovery. This is despite the fact that the detrimental impacts depend on the availability of such disturbing ions. For example, the effects of $\mathrm{K}^{+}$ions on struvite precipitation can be described by the following equation.

$$
\mathrm{Mg}^{2+}+\mathrm{HPO}_{4}^{2-}+\mathrm{K}^{+}+6 \mathrm{H}_{2} \mathrm{O} \rightarrow \mathrm{MgKPO}_{4} \cdot 6 \mathrm{H}_{2} \mathrm{O} \downarrow+\mathrm{H}^{+}
$$

It was reported that the $p K_{s p}$ values of struvite and $\mathrm{K}$-struvite were $12.60-13.36$ and 10.62, respectively (Ronteltap et al., 2007; Taylor et al., 1963). This indicates that struvite has a lower solubility and a higher formation tendency compared to K-struvite. Undoubtedly, 
ammonium and potassium ions could compete for phosphate ions during struvite formation. However, phosphate ions may have a better affinity for potassium than ammonium ions when the solution's $\mathrm{pH}$ rises from 8 to 10 (Huang et al., 2017a), in which the competitiveness of potassium ions for the phosphate ions peaks at $\mathrm{pH} 10$. Furthermore, the calcium ions which can precipitate with phosphate ions may disturb the struvite formation, as shown in Eq. (12) below.

$$
5 \mathrm{Ca}^{2+}+3 \mathrm{PO}_{4}{ }^{2-}+\mathrm{OH}^{-} \rightarrow \mathrm{Ca}_{5}(\mathrm{OH})\left(\mathrm{PO}_{4}\right)_{3} \downarrow
$$

The struvite's purity non-linearly declines to $60 \%$ when the amount of calcium in the solution increases (Li et al., 2016). This is of great significance in the practical applications because it is unfeasible for ammonium recovery to occur at high concentrations of calcium ions, especially in conditions where it is not economically feasible to add magnesium in wastewaters containing a high concentration of calcium ions. More importantly, sometimes it is also difficult to achieve $100 \%$ struvite even without the presence of calcium ions since the magnesium-based materials including brucite may be formed (Li et al., 2016). The effects of influencing parameters on ammonium recovery in the BES were summarized in Table 2.

\subsection{Osmotic membrane bioreactor}

Compared to RO, MD and ED membranes, using FO membrane requires lower energy input and is involved in less membrane fouling. Hence, the recovery of ammonium from wastewater can also occur through the osmotic membrane bioreactor (OMBR) consisting of the FO membrane and biological process. The advantage of this method is that: (i) more ammonium ions could be accumulated within the bioreactor as well as the mineral salts; (ii) less energy input is needed; (iii) decrease in membrane fouling potential could be observed; and (iv) higher quality of treated wastewater is achieved (Alturki et al., 2012; Neoh et al., 2016). Around $97 \%$ of ammonium ions in the influent were reportedly rejected by the FO membrane and then accumulated within the OMBR (Qiu \& Ting, 2014) (see Figure 4). 
Subsequently, most of the ammonium accumulated could be recovered by struvite precipitation except for the fraction of ammonium consumed by bioassimilation. There is no need to have an additional magnesium source for the precipitation because: firstly, magnesium ions were also enriched via the FO membrane in the feed side; and secondly, magnesium chloride $\left(\mathrm{MgCl}_{2}\right)$ worked as the draw solution in the OMBR, which could increase the magnesium concentration due to the reverse draw solute. Simultaneously, recovering ammonium could decrease the amount of mineral salts and thereby reduce the salinity of the OMBR. Nonetheless it should be noted here that additional sodium hydroxide $(\mathrm{NaOH})$ is still required for increasing $\mathrm{pH}$ to satisfy the struvite precipitation. Additionally, Luo et al. (2016) found that the integration of RO membrane with OMBR can largely increase the system's feasibility. The possible reason for this is that using RO membrane can (a) reconcentrate the diluted draw solution of the FO process; and (b) recover fresh water from the draw solution. Similarly, the MD membrane can also function in recovering draw solute for continuous OMBR operation (Husnain et al., 2015).

For using BES and OMBR to recover ammonium from wastewater, membrane fouling is still a challenge. However, the membrane fouling potential can be reduced to some degree in the BES when electricity generation is brought into play. Since the anaerobic sludge particles are negatively charged, the current field generated between the anode and cathode may inhibit sludge accumulating on the membrane surface due to electrostatic repulsion (Wang et al., 2013). Consequently, the membrane fouling rate decreases and moreover, the membrane fouling in the OMBR is relatively small because the FO membrane is used. Applying the FO membrane could contribute to low membrane fouling and chemical cleaning methods are conducted regularly to effectively minimize the risks of membrane fouling (Achilli et al., 2009; Yap et al., 2012). This is despite the fact that using the OMBR for ammonium recovery 
could be more expensive. The summarization of ammonium recovery in the BES/membrane hybrid system is shown in Table 3.

\section{Economic analysis of ammonium recovery}

\subsection{Costs and energy consumption associated with ammonium recovery}

The economic feasibility of ammonium recovery is determined by both operational costs and the benefits of recovered ammonium in future commercial undertakings. Ammonium recovery via struvite precipitation presents its obvious advantages: firstly, it can simultaneously recover phosphate which is a non-renewable and limited source from wastewater; and secondly, struvite is a safe and effective slow release fertilizer that be directly applied to land. In Japan, struvite was reportedly sold at a value of US\$250 per tonne in 2001 (Forrest et al., 2008; Ueno \& Fujii, 2001). Struvite formation could effectively avoid the scaling problem and benefit the sludge dewatering. Recently, one study (Waternet, 2017) found that ammonium recovery through struvite precipitation which was conducted at the WWTP, Amsterdam West, could reduce operational costs by $€ 500000(\approx$ US $\$ 583,275)$ per year. Also, the recovered struvite could be sold to the fertilizer industry at prices ranging from $€ 50(\approx$ US\$58.33)-100 ( $\approx$ US\$116.66)/t. This process could also save power of around $456 \mathrm{kwh} / \mathrm{kg} \cdot \mathrm{N}$ compared to a normal system (Bradford-Hartke et al., 2012). However, struvite precipitation requires a large amount of additional alkaline chemicals to increase $\mathrm{pH}$. Furthermore substantial magnesium materials for struvite formation may be needed due to most wastewater sources lacking a sufficient magnesium source.

With reference to the process of stripping coupled with adsorption for ammonium recovery, this approach is insensitive to feed concentration. It indicates the method can be applied to a wider range of wastewater sources. Furthermore, the selection of the acid solutions for ammonia adsorption also affects the economics of ammonium recovery. Generally, sulphuric, hydrochloric and nitric acid are mainly utilized to produce their 
associated ammonium salts. One study found that the resulting ammonium sulphate as the recovered ammonium was estimated to have a similar market value at $€ 1.0(\approx \mathrm{US} \$ 1.17) \mathrm{N} / \mathrm{kg}$ to industrial fertilizer (Desmidt et al., 2015). Nevertheless, De Vrieze et al. (2016) concluded that ammonia stripping is only economically feasible when the concentration of total ammonium nitrogen is more than 1000-1500 mg N/L. The energy consumption and costs involved in ammonium recovery through stripping-adsorption mainly include the aeration for ammonia stripping and additional chemicals. These include $\mathrm{CaO} / \mathrm{NaOH}$ (for maintaining desirable alkaline $\mathrm{pH}$ to form gaseous ammonia) and acid solution (for the subsequent adsorption of volatile ammonia to form ammonium salts), respectively. In the Veas wastewater treatment plant (Oslo, Norway), ammonium recovery from wastewater is achieved in the form of ammonium nitrate by stripping coupled with adsorption (Sagberg et al., 2006). The plant controls the practical recovery efficiency of ammonium around $88 \%$ or less since a rapid increase in energy consumption and decrease in return may occur once the recovery efficiency is over $88 \%$. Previously, ammonium recovery from dewatering centrate through air stripping at high temperature was investigated in New York at laboratory and pilot-scale, respectively (Katehis et al., 1998). In this study, 90\% of ammonium can be stripped. Nevertheless, the additional alkalinity may increase the overall costs as well as the high energy consumption used for blowers and heaters.

In addition, the energy generated from the anaerobic digestion biogas can be used to heat the liquid water while using stripping coupled with adsorption to recover ammonium. Moreover, increasing the ammonia mass flow rate to the acid solution can increase the technical and economic feasibility of ammonium recovery by stripping coupled with adsorption as well as decreasing the amount of condensed water vapour that reaches the receiving solution (Ukwuani and Tao, 2016). The stripped ammonia also has potential to react with the flue gases derived from some industries (e.g. fuelled electrical generating 
stations and incinerators), such as $\mathrm{SO}_{2}$ and $\mathrm{CO}_{2}$ (Dong et al., 2012; Liu et al., 2009). As a result of this process, ammonium salts (e.g.ammonium sulphate and ammonium bicarbonate) can be generated, which can be subsequently utilized for direct land application as a fertilizer.

Using the BES to recover ammonium is advantageous because there is no need to increase $\mathrm{pH}$ to convert ammonium into gas ammonium. Indeed, the possible energy balance associated with the ammonium recovery by the BES may include aeration in the cathode chamber, ammonia adsorption by sulphuric acid, additional power (only for the MEC), and energy generation (only for the MFC). Based on this, an analysis of energy balance for the ammonium recovery is presented in Table 4 (Kuntke et al., 2012; Maurer et al., 2003; Qin \& He, 2014).

As shown in Table 4, the MFC shows a positive energy balance for recovering ammonium while the conventional ammonia stripping requires the highest energy input. Compared to the MFC, the MEC needs an external power supply which accounts for a major proportion of total energy requirement. As for the traditional ammonia stripping, it requires the addition of alkaline chemicals for $\mathrm{pH}$ elevation and does not produce energy, compared with MFC regarding ammonium recovery. Besides, the ammonium recovery rate via MEC can obtain $162 \pm 20 \mathrm{~g} \mathrm{~N} / \mathrm{m}^{2} \mathrm{~d}$ of ammonium recovery rate with the production of hydrogen gas $\left(\mathrm{H}_{2}\right)$ despite requiring power of $8.2 \mathrm{MJ} / \mathrm{kg} \mathrm{N}$ (Kuntke et al., 2014). Wu and Modin (2013) stated that the MEC used for ammonium recovery was energetically favorable with a net energy balance ranging from 5.4 to $12.4 \mathrm{kWh} / \mathrm{kg} \cdot \mathrm{N}$. In their study, the energy input only included the external power supply while the air stripping method used to volatilize ammonia was not part of their scope. The energy output considered the generation of $\mathrm{H}_{2}$ gas and saved energy which may be used in the industrial Haber-Bosch process for ammonia production. 


\subsection{Recovered ammonium}

It is necessary to evaluate the performance of recovered ammonium in agriculture through an analysis of the crop field. Rahman et al. (2011) investigated the effects of struvite on the growth of maize and observed that struvite has a lower leaching rate and releasing rate of nutrients during the plant-growing season compared to fused superphosphate. Furthermore, many researchers have assessed the bioavailability of struvite in its application to crops and plants such as Chinese cabbage, corn and tomato plants (Ryu et al., 2012; Uysal et al., 2014; Uysal \& Kuru, 2013). Such studies found that struvite is relatively soluble and bioavailable at a wider range of $\mathrm{pH}$ conditions and soil types. Both ammonium salts and liquid ammonia also have high potential as fertilizers in agriculture. Of these, $\left(\mathrm{NH}_{4}\right)_{2} \mathrm{SO}_{4}$ can also be employed for manufacturing nitrogen polymers in industry as well as food production (Iskander et al., 2016). More importantly, when the sulphuric acid solution used to adsorb volatile ammonia is pre-saturated with ammonium sulphate, the final adsorbed form of volatile ammonia may be pure ammonium sulfate crystals (Tao \& Ukwuani, 2015). The crystals are much favoured for their use as laboratory chemicals and fertilizers.

\section{Future perspectives}

Recovered ammonium can be directly or indirectly used in agriculture, and effectively ameliorate environmental issues such as eutrophication in water bodies. Government policies and regulations should drive this process of looking after the environment if economic incentives for ammonium recovery are not enough. The integration of conventional wastewater treatment with ammonium recovery can indeed increase the economic feasibility of wastewater treatment and improve the sustainability of wastewater treatment facilities. As discussed above, ammonium recovery is only economically feasible when applied to large wastewater treatment plants that can produce large concentrations of ammonium ions. Another important issue is that treated wastewater in the ammonium recovery process needs 
proper treatment because the process may not receive $100 \%$ recovered ammonia. As well, any residual ammonia needs further treatment to satisfy the discharge standard (De Vrieze et al., 2016). Moreover, life cycle analysis (LCA) or triple bottom line (3BL) techniques can be used to quantitatively evaluate the sustainability of an ammonium recovery system, including its impacts on economics, environment and society (Lin et al., 2016).

Of all the technologies involved in recovering ammonium from wastewater, the BES is one of the most promising methods. Nevertheless, improvements still need to be made in the BES for sustainable ammonium recovery. For example, a stack of ion exchange membranes can be installed into the BES to enhance ammonium concentration (Tice \& Kim, 2014). The ammonium transfer across the membrane should be optimized so that ammonium accumulation in the cathode chamber is improved. Parameters influencing ammonium recovery from the catholyte include current density, $\mathrm{pH}$ of catholyte, membrane type and coexisting ions. It should be noted here that some of these factors do depend on each other, so their interactions need more analysis in order to improve ammonium transport and subsequent recovery. Another issue involved in ammonium recovery via BES is that ammonium recovery and energy recovery may affect each other. Specifically, high electricity generation is beneficial for ammonium transfer and its further recovery in BES, but this may result in less energy being recycled. Further research should focus on resolving this problem and ensure a BES which favors ammonium recovery is well designed.

Energy input for aeration is necessary for driving ammonia out of the catholyte and accounts for a large proportion of total energy used in this process, so how to drive ammonia out of the cathode chamber while consuming energy efficiently is still a big challenge. More importantly, scaling up BES to the industrial level for treating large volumes of wastewater requires more research shifting from the laboratory context to pilot or plant scale scenarios. Studies have suggested that ammonium is precipitated on the cathode surface of the BES 
Therefore, firstly the components of deposits should be analysed in more detail and their effects on crops and plants in terms of fertilizer efficacy should be identified; and secondly, the effects of ammonium-based precipitates on the cathode electrode's performance need further assessment. The cathode covered by the precipitates could be treated with regeneration or replacement.

Furthermore, the recovery of phosphate recovery in wastewater treatment should be also considered while enhancing ammonium recovery in the wastewater treatment process. This is because phosphate recovery can also supplement fertilizer production and lower the risk of eutrophication. Anaerobic digestion can facilitate the enrichment of ammonium with high purity, in which soluble ammonium can be separated from the effluent in downstream units and be recovered in wastewater. Research regarding ammonium recovery through anaerobic digestion coupled with other technologies needs more attention.

Even though the main focus of this paper is on ammonium recovery from wastewater, ammonium recovery could be extended to incorporate wastewater sludge. It was reported that nitrogen is also included in sludge in the form of organic nitrogen, which accounts for $3-4 \%$ of dry weight of sludge (Stein et al., 1995). Generally, ammonia volatilization could be achieved via composting, but this may result in serious environmental issues (Ogunwande et al., 2008), particularly since sulfate can be oxidized by $\mathrm{NO}_{\mathrm{x}}$ in the air (Cheng et al., 2016). This implies that searching for an approach to effectively release ammonium from the sludge is necessary. Meanwhile the method should also have the ability to separate ammonium ions from foreign substances such as heavy metals. For example, heavy metals can be immobilized into the solid phase. At mild temperatures, the method could be also implemented in order to disintegrate the labile organic nitrogen, causing the accelerated release of ammonium from sludge (He et al., 2015). 
Another issue involved in ammonium recovery through struvite precipitation is that most wastewaters contain more ammonium and phosphate than magnesium, so additional magnesium is always needed in this process (Rahman et al., 2014). If the concentration of ammonium and phosphate can satisfy the chemical requirements of struvite formation, the magnesium material utilized in this method may account for $75 \%$ of the overall costs of struvite production (Dockhorn, 2009). For this reason, researchers are currently studying inexpensive magnesium sources in struvite precipitation, but the solution is still a long way off.

\section{Conclusion}

Recovering ammonium from wastewater not only reduces the costs, energy and environmental footprint associated with this removal process. Another benefit is that the material can be used to supplement fertilizer production and save the expense required in the industrial Haber-Bosch process. Although the trade-off of BES between ammonium recovery and energy recovery significantly affects the amount of ammonium recovered and the ammonium-based precipitate influences how well the BES performs, the great potential of BES for recovering ammonium is very evident, despite the current challenges that need to be dealt with.

\section{Acknowledgement}

This review research was supported by the Centre for Technology in Water and Wastewater, University of Technology, Sydney (UTS, RIA NGO) and Korean Ministry of Environment as a "Global Top Project”, Project No. 201600220005. 


\section{References}

1. Abbona, F., Madsen, H.L., Boistelle, R. 1982. Crystallization of two magnesium phosphates, struvite and newberyite: effect of $\mathrm{pH}$ and concentration. Journal of Crystal Growth, 57(1), 6-14.

2. Achilli, A., Cath, T.Y., Marchand, E.A., Childress, A.E. 2009. The forward osmosis membrane bioreactor: a low fouling alternative to MBR processes. Desalination, 239(1), 10-21.

3. Ahn, Y., Hwang, Y., Shin, H. 2011. Application of PTFE membrane for ammonia removal in a membrane contactor. Water Science and Technology, 63(12), 2944-2948.

4. Alturki, A., McDonald, J., Khan, S.J., Hai, F.I., Price, W.E., Nghiem, L.D. 2012. Performance of a novel osmotic membrane bioreactor (OMBR) system: flux stability and removal of trace organics. Bioresource Technology, 113, 201-206.

5. Barbera, E., Bertucco, A., Kumar, S. 2018. Nutrients recovery and recycling in algae processing for biofuels production. Renewable and Sustainable Energy Reviews, 90, $28-42$.

6. Bradford-Hartke, Z., Lant, P., Leslie, G. 2012. Phosphorus recovery from centralised municipal water recycling plants. Chemical Engineering Research and Design, 90(1), $78-85$

7. Cartinella, J.L., Cath, T.Y., Flynn, M.T., Miller, G.C., Hunter, K.W., Childress, A.E. 2006. Removal of natural steroid hormones from wastewater using membrane contactor processes. Environmental Science \& Technology, 40(23), 7381-7386.

8. Chen, X., Sun, D., Zhang, X., Liang, P., Huang, X. 2015. Novel self-driven microbial nutrient recovery cell with simultaneous wastewater purification. Scientific Reports, $\mathbf{5}$, 15744 
9. Chen, X., Zhou, H., Zuo, K., Zhou, Y., Wang, Q., Sun, D., Gao, Y., Liang, P., Zhang, X., Ren, Z.J. 2017. Self-sustaining advanced wastewater purification and simultaneous in situ nutrient recovery in a novel bioelectrochemical system. Chemical Engineering Journal, 330, 692-697.

10. Cheng, Y., Zheng, G., Wei, C., Mu, Q., Zheng, B., Wang, Z., Gao, M., Zhang, Q., He, K., Carmichael, G. 2016. Reactive nitrogen chemistry in aerosol water as a source of sulfate during haze events in China. Science Advances, 2(12), e1601530.

11. Cusick, R.D., Logan, B.E. 2012. Phosphate recovery as struvite within a single chamber microbial electrolysis cell. Bioresource Technology, 107, 110-115.

12. Dai, L., Wu, B., Tan, F., He, M., Wang, W., Qin, H., Tang, X., Zhu, Q., Pan, K., Hu, Q. 2014. Engineered hydrochar composites for phosphorus removal/recovery: Lanthanum doped hydrochar prepared by hydrothermal carbonization of lanthanum pretreated rice straw. Bioresource Technology, 161, 327-332.

13. De Vrieze, J., Smet, D., Klok, J., Colsen, J., Angenent, L.T., Vlaeminck, S.E. 2016. Thermophilic sludge digestion improves energy balance and nutrient recovery potential in full-scale municipal wastewater treatment plants. Bioresource Technology, 218, $1237-1245$.

14. Desmidt, E., Ghyselbrecht, K., Zhang, Y., Pinoy, L., Van der Bruggen, B., Verstraete, W., Rabaey, K., Meesschaert, B. 2015. Global phosphorus scarcity and full-scale Precovery techniques: a review. Critical Reviews in Environmental Science and Technology, 45(4), 336-384.

15. Dockhorn, T. 2009. About the economy of phosphorus recovery. In: International conference on nutrient recovery from wastewater streams. pp. 145-158. 
16. Dong, R., Lu, H., Yu, Y., Zhang, Z. 2012. A feasible process for simultaneous removal of $\mathrm{CO}_{2}, \mathrm{SO}_{2}$ and $\mathrm{NO}_{\mathrm{x}}$ in the cement industry by $\mathrm{NH} 3$ scrubbing. Applied Energy, 97, 185-191.

17. El-Bourawi, M., Khayet, M., Ma, R., Ding, Z., Li, Z., Zhang, X. 2007. Application of vacuum membrane distillation for ammonia removal. Journal of Membrane Science, 301(1), 200-209.

18. Erisman, J.W., Galloway, J.N., Seitzinger, S., Bleeker, A., Dise, N.B., Petrescu, A.R., Leach, A.M., de Vries, W. 2013. Consequences of human modification of the global nitrogen cycle. Philosophical Transactions of the Royal Society B, 368(1621), 20130116.

19. FAO. 2017. Current World Fertilizer Trends and Outlook to 2020. http://www.fao.org/3/a-i6895e.pdf(Accessed: 19.07.2018).

20. Foley, J., De Haas, D., Hartley, K., Lant, P. 2010. Comprehensive life cycle inventories of alternative wastewater treatment systems. Water Research, 44(5), 16541666.

21. Forrest, A., Fattah, K., Mavinic, D., Koch, F.A. 2008. Optimizing struvite production for phosphate recovery in WWTP. Journal of Environmental Engineering, 134(5), $395-402$.

22. Fowler, D., Coyle, M., Skiba, U., Sutton, M.A., Cape, J.N., Reis, S., Sheppard, L.J., Jenkins, A., Grizzetti, B., Galloway, J.N. 2013. The global nitrogen cycle in the twenty-first century. Philosophical Transactions of the Royal Society B, 368(1621), 20130164.

23. Galloway, J.N., Cowling, E.B. 2002. Reactive nitrogen and the world: 200 years of change. AMBIO: A Journal of the Human Environment, 31(2), 64-71. 
24. Gao, Y., Fang, Z., Liang, P., Huang, X. 2018. Direct concentration of municipal sewage by forward osmosis and membrane fouling behavior. Bioresource Technology, 247, $730-735$.

25. He, C., Wang, K., Yang, Y., Amaniampong, P.N., Wang, J.-Y. 2015. Effective nitrogen removal and recovery from dewatered sewage sludge using a novel integrated system of accelerated hydrothermal deamination and air stripping. Environmental Science \& Technology, 49(11), 6872-6880.

26. Heffer, P., Prud'homme, M. 2014. Fertilizer Outlook 2014-2018. In: 82nd IFA Annual Conference, Sydeny.

27. Hirooka, K., Ichihashi, O. 2013. Phosphorus recovery from artificial wastewater by microbial fuel cell and its effect on power generation. Bioresource Technology, 137, $368-375$.

28. Huang, H., Yang, J., Li, D. 2014. Recovery and removal of ammonia-nitrogen and phosphate from swine wastewater by internal recycling of struvite chlorination product. Bioresource Technology, 172, 253-259.

29. Huang, H., Zhang, D., Li, J., Guo, G., Tang, S. 2017a. Phosphate recovery from swine wastewater using plant ash in chemical crystallization. Journal of Cleaner Production, $168,338-345$.

30. Huang, J., Kankanamge, N.R., Chow, C., Welsh, D.T., Li, T., Teasdale, P.R. 2017 b. Removing ammonium from water and wastewater using cost-effective adsorbents: A review. Journal of Environmental Sciences.

31. Husnain, T., Mi, B., Riffat, R. 2015. A combined forward osmosis and membrane distillation system for sidestream treatment. Journal of Water Resource and Protection, 7(14), 1111. 
32. Ichihashi, O., Hirooka, K. 2012. Removal and recovery of phosphorus as struvite from swine wastewater using microbial fuel cell. Bioresource Technology, 114, 303307.

33. Iskander, S.M., Brazil, B., Novak, J.T., He, Z. 2016. Resource recovery from landfill leachate using bioelectrochemical systems: Opportunities, challenges, and perspectives. Bioresource Technology, 201, 347-354.

34. Katehis, D., Diyamandoglu, V., Fillos, J. 1998. Stripping and recovery of ammonia from centrate of anaerobically digested biosolids at elevated temperatures. Water Environment Research, 70(2), 231-240.

35. Kelly, P.T., He, Z. 2014. Nutrients removal and recovery in bioelectrochemical systems: a review. Bioresource Technology, 153, 351-360.

36. Kim, T., An, J., Jang, J.K., Chang, I.S. 2015. Coupling of anaerobic digester and microbial fuel cell for COD removal and ammonia recovery. Bioresource Technology, 195, 217-222.

37. Kuntke, P., Sleutels, T., Saakes, M., Buisman, C. 2014. Hydrogen production and ammonium recovery from urine by a Microbial Electrolysis Cell. International Journal of Hydrogen Energy, 39(10), 4771-4778.

38. Kuntke, P., Śmiech, K., Bruning, H., Zeeman, G., Saakes, M., Sleutels, T., Hamelers, H., Buisman, C. 2012. Ammonium recovery and energy production from urine by a microbial fuel cell. Water Research, 46(8), 2627-2636.

39. Kwan, T.H., Hu, Y., Lin, C.S.K. 2016. Valorisation of food waste via fungal hydrolysis and lactic acid fermentation with Lactobacillus casei Shirota. Bioresource Technology, 217, 129-136. 
40. Ledezma, P., Kuntke, P., Buisman, C.J., Keller, J., Freguia, S. 2015. Source-separated urine opens golden opportunities for microbial electrochemical technologies. Trends in Biotechnology, 33(4), 214-220.

41. Li, B., Boiarkina, I., Young, B., Yu, W. 2016. Quantification and mitigation of the negative impact of calcium on struvite purity. Advanced Powder Technology, 27(6), $2354-2362$.

42. Li, R.-h., Li, B., Li, X.-y. 2018. An integrated membrane bioreactor system with irondosing and side-stream co-fermentation for enhanced nutrient removal and recovery: System performance and microbial community analysis. Bioresource Technology, 260, $248-255$.

43. Lin, Y., Guo, M., Shah, N., Stuckey, D.C. 2016. Economic and environmental evaluation of nitrogen removal and recovery methods from wastewater. Bioresource Technology, 215, 227-238.

44. Liu, J., Wang, S., Zhao, B., Tong, H., Chen, C. 2009. Absorption of carbon dioxide in aqueous ammonia. Energy Procedia, 1(1), 933-940.

45. Liu, S., Li, L., Li, H., Wang, H., Yang, P. 2017. Study on ammonium and organics removal combined with electricity generation in a continuous flow microbial fuel cell. Bioresource Technology, 243, 1087-1096.

46. Logan, B.E., Call, D., Cheng, S., Hamelers, H.V., Sleutels, T.H., Jeremiasse, A.W., Rozendal, R.A. 2008. Microbial electrolysis cells for high yield hydrogen gas production from organic matter. Environmental Science \& Technology, 42(23), 86308640.

47. Logan, B.E., Hamelers, B., Rozendal, R., Schröder, U., Keller, J., Freguia, S., Aelterman, P., Verstraete, W., Rabaey, K. 2006. Microbial fuel cells: methodology and technology. Environmental Science \& Technology, 40(17), 5181-5192. 
48. Luo, P., Liu, F., Zhang, S., Li, H., Yao, R., Jiang, Q., Xiao, R., Wu, J. 2018. Nitrogen removal and recovery from lagoon-pretreated swine wastewater by constructed wetlands under sustainable plant harvesting management. Bioresource Technology, 258, 247-254.

49. Luo, W., Hai, F.I., Price, W.E., Guo, W., Ngo, H.H., Yamamoto, K., Nghiem, L.D. 2016. Phosphorus and water recovery by a novel osmotic membrane bioreactorreverse osmosis system. Bioresource Technology, 200, 297-304.

50. Ma, B., Wang, S., Cao, S., Miao, Y., Jia, F., Du, R., Peng, Y. 2016. Biological nitrogen removal from sewage via anammox: recent advances. Bioresource Technology, 200, 981-990.

51. Maurer, M., Schwegler, P., Larsen, T. 2003. Nutrients in urine: energetic aspects of removal and recovery. Water Science and Technology, 48(1), 37-46.

52. Mondor, M., Ippersiel, D., Lamarche, F., Masse, L. 2009. Fouling characterization of electrodialysis membranes used for the recovery and concentration of ammonia from swine manure. Bioresource Technology, 100(2), 566-571.

53. Mondor, M., Masse, L., Ippersiel, D., Lamarche, F., Masse, D. 2008. Use of electrodialysis and reverse osmosis for the recovery and concentration of ammonia from swine manure. Bioresource Technology, 99(15), 7363-7368.

54. Mulchandani, A., Westerhoff, P. 2016. Recovery opportunities for metals and energy from sewage sludges. Bioresource Technology, 215, 215-226.

55. Nancharaiah, Y., Mohan, S.V., Lens, P. 2016. Recent advances in nutrient removal and recovery in biological and bioelectrochemical systems. Bioresource Technology, 215, 173-185. 
56. Nancharaiah, Y., Reddy, G.K.K. 2017. Aerobic granular sludge technology: mechanisms of granulation and biotechnological applications. Bioresource Technology.

57. Nancharaiah, Y.V., Venugopalan, V.P. 2011. Denitrification of synthetic concentrated nitrate wastes by aerobic granular sludge under anoxic conditions. Chemosphere, 85(4), 683-688.

58. Neoh, C.H., Noor, Z.Z., Mutamim, N.S.A., Lim, C.K. 2016. Green technology in wastewater treatment technologies: Integration of membrane bioreactor with various wastewater treatment systems. Chemical Engineering Journal, 283, 582-594.

59. Ogunwande, G., Osunade, J., Adekalu, K., Ogunjimi, L. 2008. Nitrogen loss in chicken litter compost as affected by carbon to nitrogen ratio and turning frequency. Bioresource Technology, 99(16), 7495-7503.

60. Patil, S.A., Harnisch, F., Koch, C., Hübschmann, T., Fetzer, I., Carmona-Martínez, A.A., Müller, S., Schröder, U. 2011. Electroactive mixed culture derived biofilms in microbial bioelectrochemical systems: the role of $\mathrm{pH}$ on biofilm formation, performance and composition. Bioresource Technology, 102(20), 9683-9690.

61. Qin, J.-J., Oo, M.H., Wai, M.N., Wong, F.-S. 2003. Effect of feed pH on an integrated membrane process for the reclamation of a combined rinse water from electroless nickel plating. Journal of Membrane Science, 217(1), 261-268.

62. Qin, M., He, Z. 2014. Self-supplied ammonium bicarbonate draw solute for achieving wastewater treatment and recovery in a microbial electrolysis cell-forward osmosiscoupled system. Environmental Science \& Technology Letters, 1(10), 437-441.

63. Qin, M., Molitor, H., Brazil, B., Novak, J.T., He, Z. 2016. Recovery of nitrogen and water from landfill leachate by a microbial electrolysis cell-forward osmosis system. Bioresource Technology, 200, 485-492. 
64. Qiu, G., Ting, Y.-P. 2014. Direct phosphorus recovery from municipal wastewater via osmotic membrane bioreactor (OMBR) for wastewater treatment. Bioresource Technology, 170, 221-229.

65. Rahman, M.M., Liu, Y., Kwag, J.-H., Ra, C. 2011. Recovery of struvite from animal wastewater and its nutrient leaching loss in soil. Journal of Hazardous Materials, 186(2), 2026-2030.

66. Rahman, M.M., Salleh, M.A.M., Rashid, U., Ahsan, A., Hossain, M.M., Ra, C.S. 2014. Production of slow release crystal fertilizer from wastewaters through struvite crystallization-A review. Arabian Journal of Chemistry, 7(1), 139-155.

67. Rao, U., Posmanik, R., Hatch, L.E., Tester, J.W., Walker, S.L., Barsanti, K.C., DavidJassby. 2018. Coupling hydrothermal liquefaction and membrane distillation to treat anaerobic digestate from food and dairy farm waste. Bioresource Technology, 267, 408-415.

68. Ravikumar, R., Chandrasekhar, A., Krishna, C.R., Reddy, Y. 2010. X-ray powder diffraction, thermal analysis and IR studies of zinc ammonium phosphate hexahydrate. Optoelectronics and Advanced Materials-Rapid Communications, 4, 215-219.

69. Ronteltap, M., Maurer, M., Gujer, W. 2007. Struvite precipitation thermodynamics in source-separated urine. Water Research, 41(5), 977-984.

70. Rozendal, R.A., Leone, E., Keller, J., Rabaey, K. 2009. Efficient hydrogen peroxide generation from organic matter in a bioelectrochemical system. Electrochemistry Communications, 11(9), 1752-1755.

71. Ryu, H.-D., Lim, C.-S., Kang, M.-K., Lee, S.-I. 2012. Evaluation of struvite obtained from semiconductor wastewater as a fertilizer in cultivating Chinese cabbage. Journal of Hazardous Materials, 221, 248-255. 
72. Sagberg, P., Ryrfors, P., Berg, K.G. 2006. 10 Years of operation of an integrated nutrient removal treatment plant, part 2: sludge and side stream treatment. http://www.veas.nu/upload/file/english/10years.pdf (Accessed: 19.07.2018).

73. Schuiling, R., Andrade, A. 1999. Recovery of struvite from calf manure. Environmental Technology, 20(7), 765-768.

74. Shoda, M., Ishikawa, Y. 2014. Heterotrophic nitrification and aerobic denitrification of high-strength ammonium in anaerobically digested sludge by Alcaligenes faecalis strain No. 4. Journal of Bioscience and Bioengineering, 117(6), 737-741.

75. Smith, D.P., Smith, N.T. 2015. Anaerobic-ion exchange (AN-IX) process for localscale nitrogen recovery from wastewater. Bioresource Technology, 196, 324-331.

76. Sotres, A., Cerrillo, M., Viñas, M., Bonmatí, A. 2015. Nitrogen recovery from pig slurry in a two-chambered bioelectrochemical system. Bioresource Technology, 194, 373-382.

77. Stein, L., Boulding, R., Helmick, J., Murphy, P. 1995. Process design manual: land application of sewage sludge and domestic septage. Cincinnati, Ohio: US Environmental Protection Agency.

78. Taddeo, R., Honkanen, M., Kolppo, K., Lepistö, R. 2018. Nutrient management via struvite precipitation and recovery from various agroindustrial wastewaters: Process feasibility and struvite quality. Journal of Environmental Management, 212, 433-439.

79. Tansel, B., Lunn, G., Monje, O. 2018. Struvite formation and decomposition characteristics for ammonia and phosphorus recovery: A review of magnesiumammonia-phosphate interactions. Chemosphere, 194, 504-514.

80. Tao, W., Ukwuani, A.T. 2015. Coupling thermal stripping and acid absorption for ammonia recovery from dairy manure: Ammonia volatilization kinetics and effects of 
temperature, $\mathrm{pH}$ and dissolved solids content. Chemical Engineering Journal, 280, 188-196.

81. Tarayre, C., De Clercq, L., Charlier, R., Michels, E., Meers, E., Camargo-Valero, M., Delvigne, F. 2016. New perspectives for the design of sustainable bioprocesses for phosphorus recovery from waste. Bioresource Technology, 206, 264-274.

82. Taylor, A., Frazier, A., Gurney, E. 1963. Solubility products of magnesium ammonium and magnesium potassium phosphates. Transactions of the Faraday Society, 59, 1580-1584.

83. Tice, R.C., Kim, Y. 2014. Energy efficient reconcentration of diluted human urine using ion exchange membranes in bioelectrochemical systems. Water Research, 64, $61-72$

84. Ueno, Y., Fujii, M. 2001. Three years experience of operating and selling recovered struvite from full-scale plant, Environmental Technology, 22(11), 1373-1381.

85. Ukwuani, A.T., Tao, W. 2016. Developing a vacuum thermal stripping-acid absorption process for ammonia recovery from anaerobic digester effluent. Water Research, 106, 108-115.

86. Uysal, A., Demir, S., Sayilgan, E., Eraslan, F., Kucukyumuk, Z. 2014. Optimization of struvite fertilizer formation from baker's yeast wastewater: growth and nutrition of maize and tomato plants. Environmental Science and Pollution Research, 21(5), $3264-3274$.

87. Uysal, A., Kuru, B. 2013. Magnesium Ammonium Phosphate Production from Wastewater through Box-Behnken Design and Its Effect on Nutrient Element Uptake in Plants. CLEAN-Soil, Air, Water, 41(5), 447-454. 
88. Wang, Y.-K., Li, W.-W., Sheng, G.-P., Shi, B.-J., Yu, H.-Q. 2013. In-situ utilization of generated electricity in an electrochemical membrane bioreactor to mitigate membrane fouling. Water Research, 47(15), 5794-5800.

89. Waternet. 2017. Oral Presentation. Enhanced sewage sludge treatment with struvite recovery. Struvite as phosphate fertilizer. In: Big Phosphorus Conference, Manchester.

90. Wu, X., Modin, O. 2013. Ammonium recovery from reject water combined with hydrogen production in a bioelectrochemical reactor. Bioresource Technology, 146, $530-536$.

91. Xie, M., Shon, H.K., Gray, S.R., Elimelech, M. 2016. Membrane-based processes for wastewater nutrient recovery: Technology, challenges, and future direction. Water Research, 89, 210-221.

92. Xue, W., Tobino, T., Nakajima, F., Yamamoto, K. 2015. Seawater-driven forward osmosis for enriching nitrogen and phosphorous in treated municipal wastewater: Effect of membrane properties and feed solution chemistry. Water Research, 69, 120130.

93. Yan, T., Ye, Y., Ma, H., Zhang, Y., Guo, W., Du, B., Wei, Q., Wei, D., Ngo, H.H. 2018. A critical review on membrane hybrid system for nutrient recovery from wastewater. Chemical Engineering Journal, 348, 143-156.

94. Yang, Y., Li, X., Yang, X., He, Z. 2017. Enhanced nitrogen removal by membraneaerated nitritation-anammox in a bioelectrochemical system. Bioresource Technology, 238, 22-29.

95. Yap, W.J., Zhang, J., Lay, W.C., Cao, B., Fane, A.G., Liu, Y. 2012. State of the art of osmotic membrane bioreactors for water reclamation. Bioresource Technology, 122, 217-222. 
96. Ye, L., Li, D., Zhang, J., Zeng, H. 2018. Resuscitation of starved anaerobic ammonium oxidation sludge system: impacts of repeated short-term starvation. Bioresource Technology.

97. Ye, Y., Hu, Y., Hussain, Z., Li, X., Li, D., Kang, J. 2016a. Simultaneous adsorptive removal of fluoride and phosphate by magnesia-pullulan composite from aqueous solution. RSC Advances, 6(42), 35966-35976.

98. Ye, Y., Ngo, H.H., Guo, W., Liu, Y., Li, J., Liu, Y., Zhang, X., Jia, H. 2017. Insight into chemical phosphate recovery from municipal wastewater. Science of the Total Environment, 576, 159-171.

99. Ye, Y., Ngo, H.H., Guo, W., Liu, Y., Zhang, X., Guo, J., Ni, B.-j., Chang, S.W., Nguyen, D.D. 2016b. Insight into biological phosphate recovery from sewage. Bioresource Technology, 218, 874-881.

100. Yu, Y., Lei, Z., Yuan, T., Jiang, Y., Chen, N., Feng, C., Shimizu, K., Zhang, Z. 2017. Simultaneous phosphorus and nitrogen recovery from anaerobically digested sludge using a hybrid system coupling hydrothermal pretreatment with MAP precipitation. Bioresource Technology, 243, 634-640.

101. Zarebska, A., Amor, A.C., Ciurkot, K., Karring, H., Thygesen, O., Andersen, T.P., Hägg, M.-B., Christensen, K.V., Norddahl, B. 2015. Fouling mitigation in membrane distillation processes during ammonia stripping from pig manure. Journal of Membrane Science, 484, 119-132.

102. Zhang, F., Li, J., He, Z. 2014. A new method for nutrients removal and recovery from wastewater using a bioelectrochemical system. Bioresource Technology, 166, 630-634. 
103. Zhang, L., Yang, J., Hira, D., Fujii, T., Furukawa, K. 2011. High-rate partial nitrification treatment of reject water as a pretreatment for anaerobic ammonium oxidation (anammox). Bioresource Technology, 102(4), 3761-3767. 


\section{Ammonium recovery from wastewater for sustainable wastewater management}

\section{Figure captions.}

Figure 1. The natural nitrogen cycle including major natural and anthropogenic processes (adopted from Nancharaiah et al. (2016)). This cycle involves nitrogen gas $\left(\mathrm{N}_{2}\right)$, ammonium ion $\left(\mathrm{NH}_{4}{ }^{+}\right)$, organic nitrogen, nitrate $\left(\mathrm{NO}_{3}{ }^{-}\right)$and nitrite $\left(\mathrm{NO}_{2}{ }^{-}\right) . \mathrm{NH}_{4}{ }^{+}$is stepwise oxidized through $\mathrm{NH}_{3} \mathrm{NO}$ and $\mathrm{NO}_{2}$ to $\mathrm{NO}_{3}{ }^{-}$(called nitrification). $\mathrm{NO}_{2}^{-}, \mathrm{NO}$ and $\mathrm{N}_{2} \mathrm{O}$ are the intermediate products of denitrification.

Figure 2. Schematic of (a) microbial fuel cell (MFC) and (b) microbial electrolysis cells (MEC); : anaerobic microorganism; $\bullet$ : gas $\left(\mathrm{O}_{2}\right.$ for MFC and $\mathrm{H}_{2}$ for $\left.\mathrm{MEC}\right)$; PS: power supply; CEM: cation exchange membrane. The organics are anaerobically oxidized to release electrons and protons in the anode chamber while the released electrons and protons react in the MFC's cathode chamber (for the hydroxyl generation) and MEC's cathode chamber (for the hydrogen gas generation), respectively.

Figure 3. Schematic of MEC-FO process for treating landfill leachate with simultaneous recovery of ammonium and fresh water; MEC: microbial electrolysis cells (MEC); : anaerobic microorganism; • : gas $\left(\mathrm{H}_{2}\right.$ and $\left.\mathrm{NH}_{3}\right)$; PS: power supply; CEM: cation exchange membrane.; FO: forward osmosis. A MEC could recover ammonium in the form of ammonium carbonate which could be used as the draw solute for the FO process to recover fresh water.

Figure. 4 Schematic of the OMBR for ammonium recovery (adapted from Qiu and Ting (2014)).OMBR: osmotic membrane bioreactor; FO: forward osmosis. The ammonium ions could be rejected and then concentrated in the OMBR, which could be subsequently recovered by struvite precipitation with additional sodium hydroxide. 


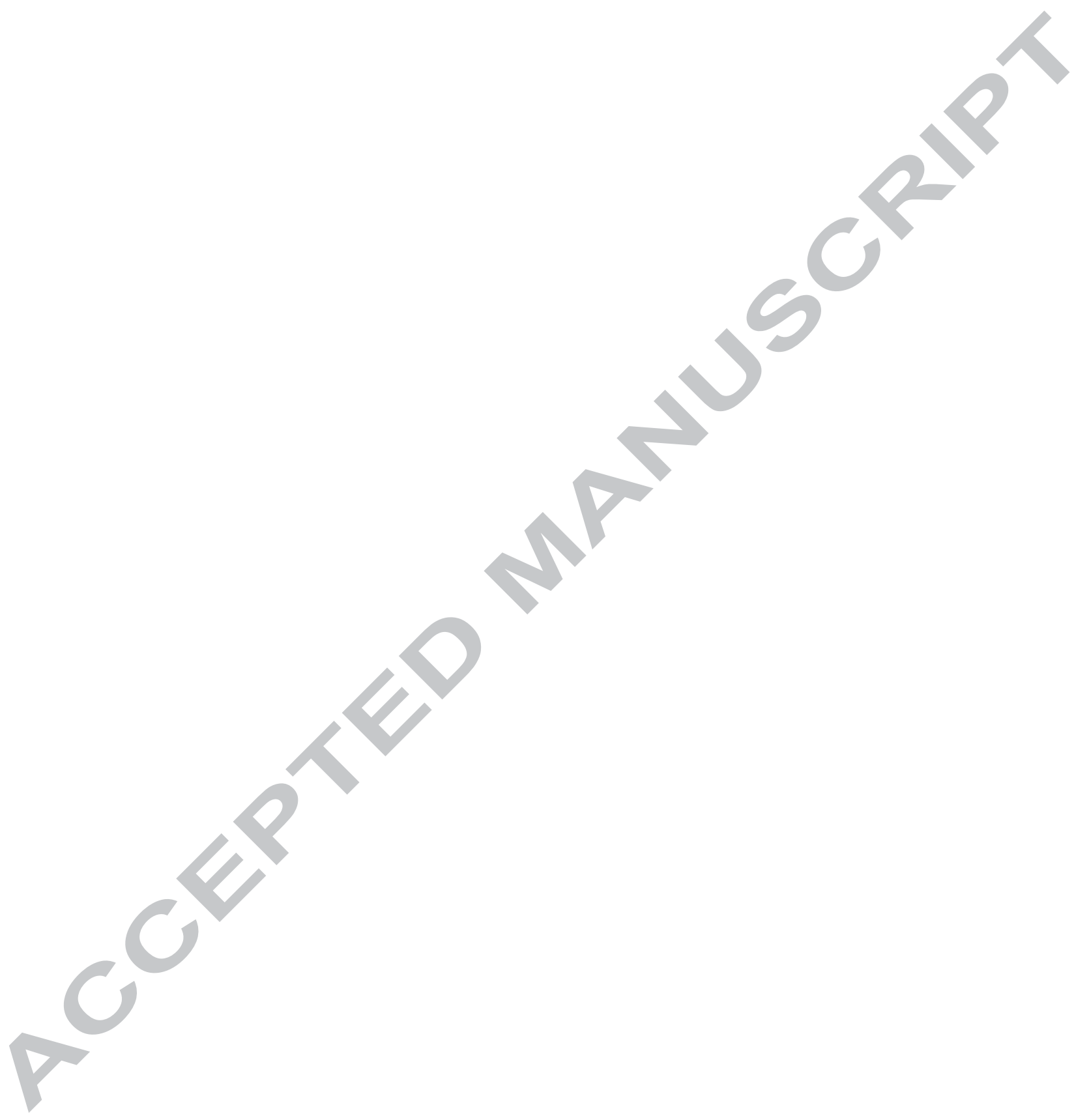




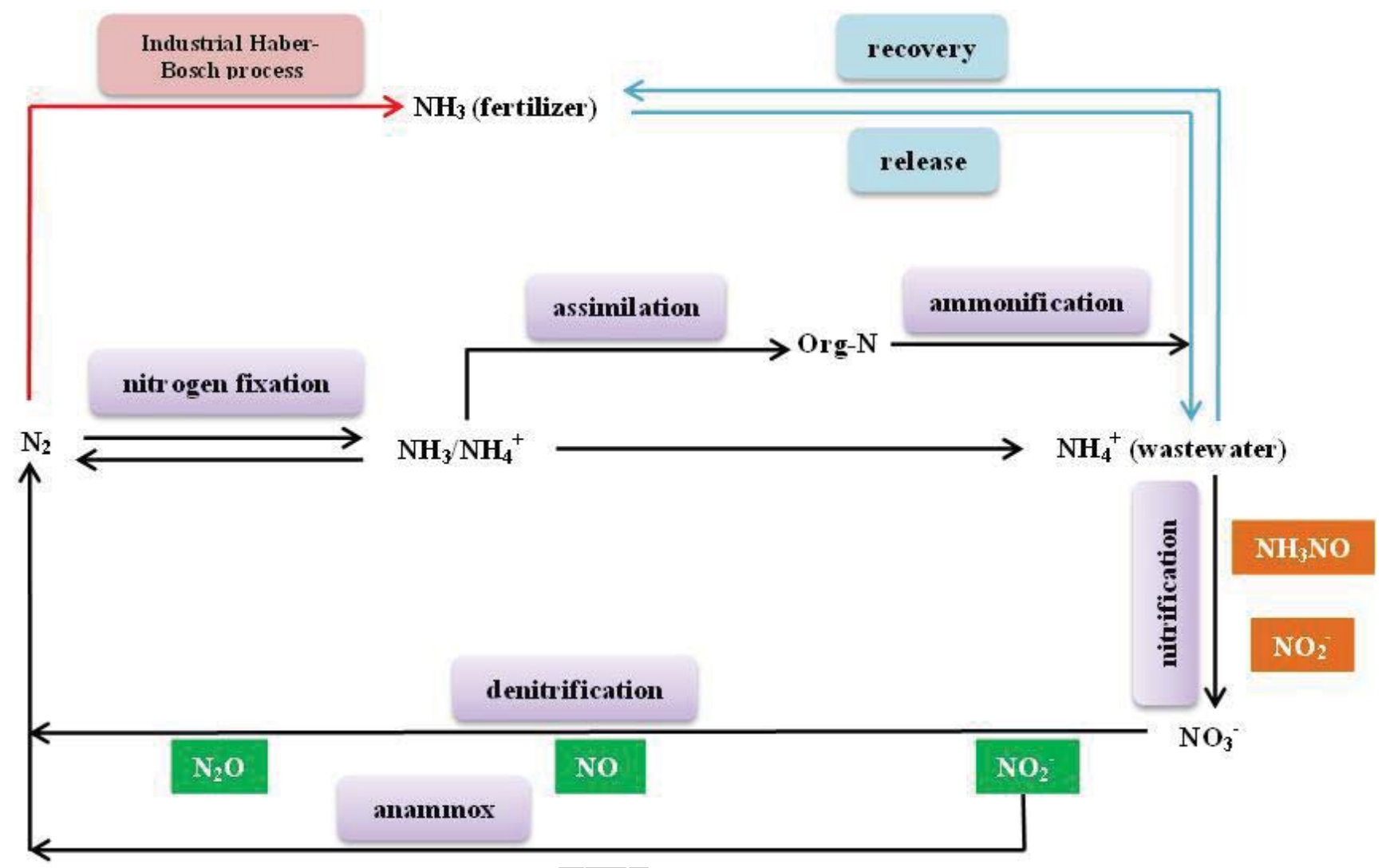

Fig. 1 


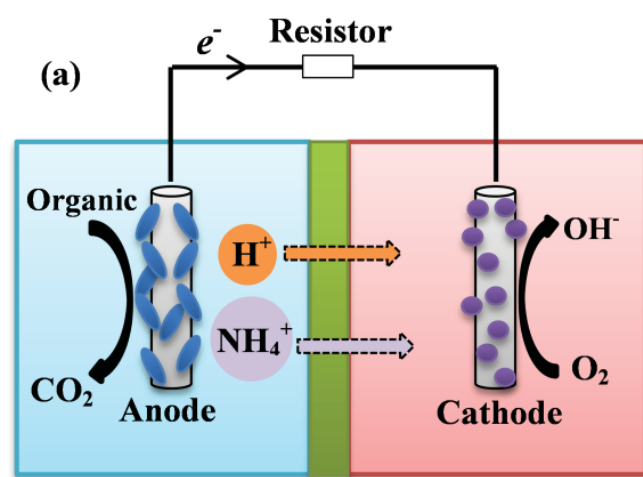

CEM

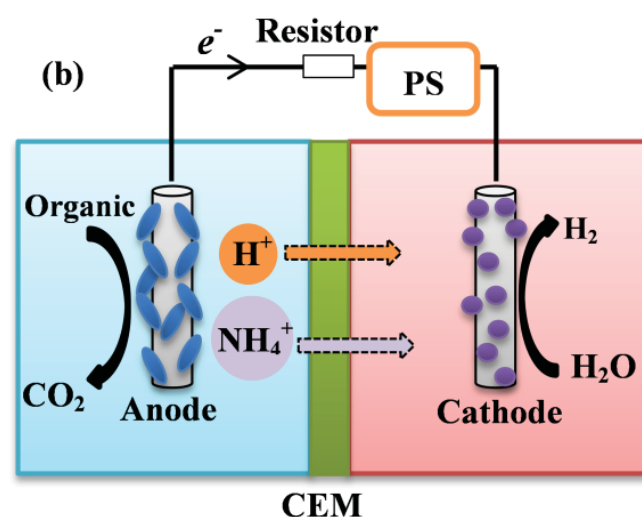

Fig. 2 


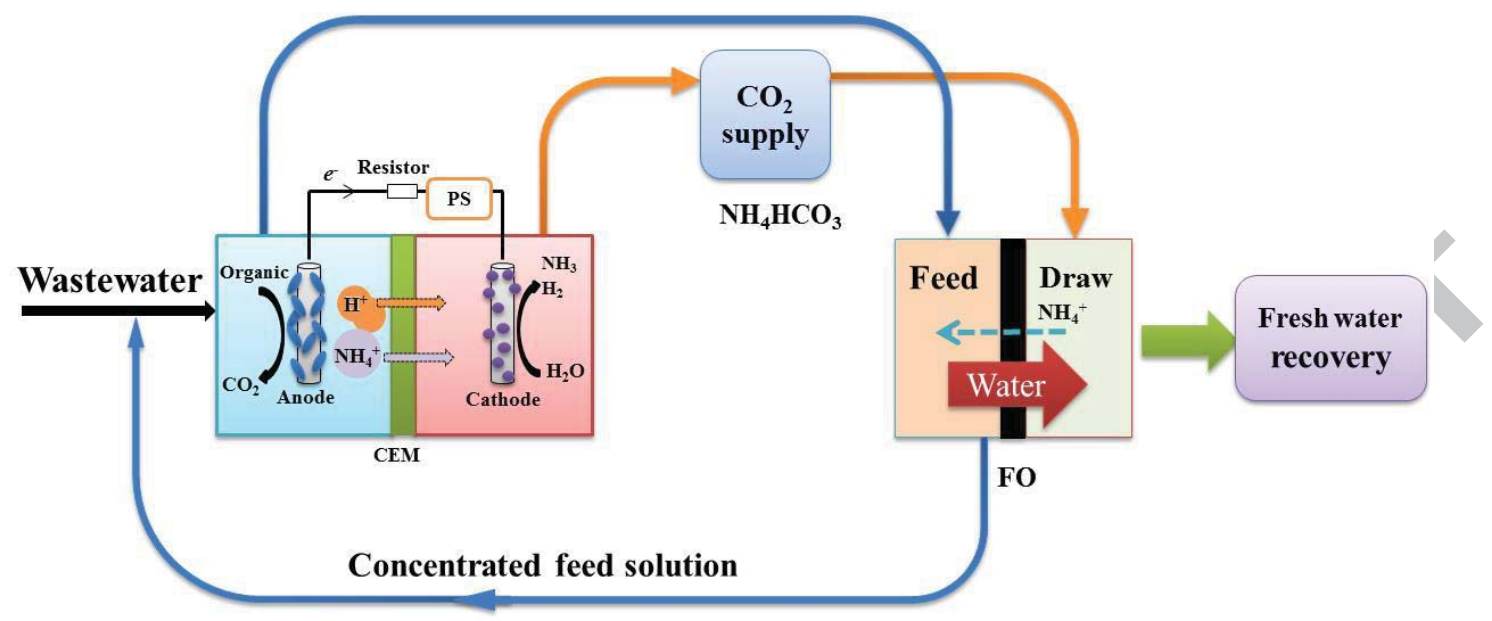

Fig. 3 


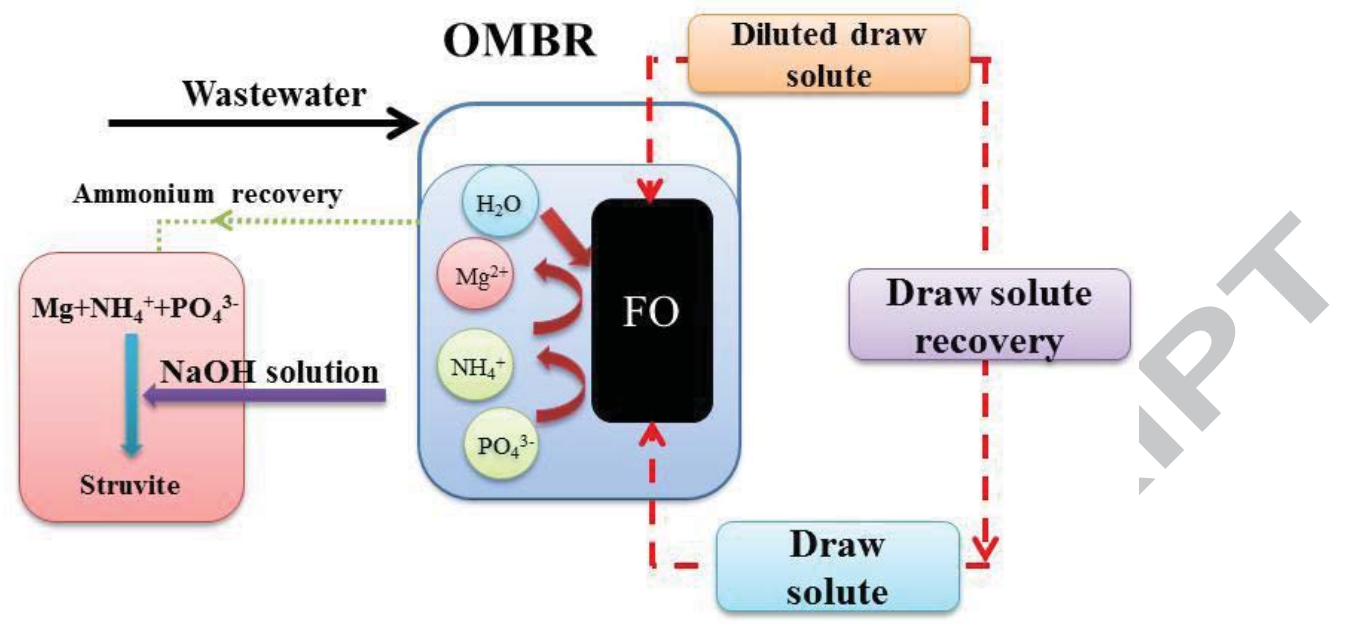

Fig. 4 
Ammonium recovery from wastewater for sustainable wastewater management

\section{Table captions}

Table 1 Ammonium content in the main types of wastewater sources

Table 2 Effects of influencing parameters on ammonium recovery in the BES

Table 3 Ammonium recovery in the BES/membrane hybrid system

Table 4 Comparison of energy balance involved in the ammonium recovery processes 
Table 1

\begin{tabular}{ccc}
\hline Wastewater sources & $\mathrm{NH}_{4}{ }^{+}-\mathrm{N}$ concentration & Reference \\
& $(\mathrm{mg} / \mathrm{L})$ & \\
\hline $\begin{array}{c}\text { Municipal wastewater } \\
\text { Human urine }\end{array}$ & $\sim 100$ & Ma et al. (2016) \\
& & Nancharaiah and Reddy \\
Landfill leachate & $\sim 9000$ & $(2017)$ \\
$\begin{array}{c}\text { Reject water } \\
\text { Kydrolysates of food waste } \\
\text { ydrolysate of anaerobically } \\
\text { digested sludge }\end{array}$ & $\sim 2000$ & Kuntke et al. (2012) \\
& $\sim 1000$ & Iskander et al. (2016) \\
& $\sim 1081$ & $\begin{array}{c}\text { Zhang et al. (2011) } \\
\text { Kwan et al. (2016) } \\
\text { Yu et al. (2017) }\end{array}$ \\
& $\sim 1000$ & Shoda and Ishikawa (2014) \\
\hline
\end{tabular}


Table 2

Influencing parameters Effects

References

(1) High current density increases the

Kim et al. (2015)

Current density ammonium migration.

Wu and Modin (2013)

(2) High current density facilitates the $\mathrm{pH}$

Zhang et al. (2014) elevation of catholyte.

(1) Influence the ammonium migration.

(2) Affect the electricity generation.

Kim et al. (2015)

Qin et al. (2016)

Coexisting cations

(3) Exert negative impacts on ammonium

Huang et al. (2017a)

recovery by struvite precipitation.

Li et al. (2016)

Ravikumar et al. (2010) 
Table 3

\begin{tabular}{|c|c|c|c|c|}
\hline $\begin{array}{l}\text { Method for ammonium } \\
\text { recovery }\end{array}$ & $\begin{array}{c}\text { Wastewater } \\
\text { source }\end{array}$ & Performance & Overall costs & Reference \\
\hline Single-chamber MFC & $\begin{array}{c}\text { Artificial } \\
\text { wastewater }\end{array}$ & Recovery as struvite & $\begin{array}{l}\text { Additional magnesium } \\
\text { source }\end{array}$ & $\begin{array}{l}\text { Ichihashi and Hirooka } \\
\text { (2012) }\end{array}$ \\
\hline Single-chamber MFC & $\begin{array}{l}\text { Synthetic } \\
\text { wastewater }\end{array}$ & $\begin{array}{l}\text { Recovery of struvite } \\
\text { at } 0.3-0.9 \mathrm{~g} / \mathrm{m}^{2} \cdot \mathrm{h}\end{array}$ & $\begin{array}{l}\text { External power supply } \\
\text { hydrogen production }\end{array}$ & $\begin{array}{l}\text { Cusick and Logan } \\
\text { (2012) }\end{array}$ \\
\hline Double-chamber MEC & $\begin{array}{l}\text { Landfill } \\
\text { leachate }\end{array}$ & $\begin{array}{l}54.1 \% \text { of ammonium } \\
\text { recovered }\end{array}$ & $\begin{array}{l}\text { Fresh water recovery } \\
\text { External power supply }\end{array}$ & Qin et al. (2016) \\
\hline Multi-chamber BES & $\begin{array}{l}\text { Domestic } \\
\text { wastewater }\end{array}$ & $\begin{array}{l}\text { Concentration } \\
\text { factors: ammonium }\end{array}$ & Energy neutral approach & Chen et al. (2017) \\
\hline OMBR & Municipal & $97 \%$ of ammonium & Additional $\mathrm{NaOH}$ & Qiu and Ting (2014) \\
\hline
\end{tabular}

MFC: microbial fuel cells; MEC: microbial electrolysis cells; OMBR: osmotic membrane bioreactor

\section{Table 4}

\begin{tabular}{lccc}
\hline & MFC & MEC & Classical ammonia stripping \\
\hline nergy consumption $\left(\mathrm{kJ} \cdot \mathrm{g}^{-1} \mathrm{~N}\right)$ & 10.93 & 18.36 & 26.3 \\
et energy yield $\left(\mathrm{kJ} \cdot \mathrm{g}^{-1} \mathrm{~N}\right)$ & 3.46 & -18.36 & -32.5 \\
mmonium recovery rate $\left(\mathrm{g}^{-1} \mathrm{~N} \cdot \mathrm{d}^{-1} \cdot \mathrm{m}^{-2}\right)^{\mathrm{a}}$ & 3.29 & 7.59 & $\mathrm{~N} / \mathrm{A}$ \\
\hline
\end{tabular}


${ }^{\mathrm{a}}$ The ammonium recovery rate represents the daily amount of $\mathrm{N}$ recovered per surface area of

CAM. MFC: microbial fuel cells; MEC: microbial electrolysis cells. 